\title{
EVAPORITE KARST IN THE PERMIAN BASIN REGION OF WEST TEXAS AND SOUTHEASTERN NEW MEXICO: THE HUMAN IMPACT
}

\author{
Lewis Land \\ National Cave and Karst Research Institute, and New Mexico Bureau of Geology and Mineral Resources, New \\ Mexico Tech 400-1 Cascades Ave., Carlsbad, NM, 88220,USA, lland@nckri.org
}

\begin{abstract}
A significant minority of sinkholes in the greater Permian Basin region of west Texas and southeastern New Mexico are of human origin. These anthropogenic sinkholes are often associated with historic oil field activity, or with solution mining of Permian salt beds in the shallow subsurface. The well-known Wink Sinks in Winkler Co., Texas formed in 1980 and 2002 within the giant Hendrick oil field. The Wink Sinks were probably the result of subsurface dissolution of salt caused by fresh water leakage in improperly cased abandoned oil wells. In 2008 two catastrophic sinkhole events occurred a few months apart in northern Eddy Co., New Mexico, and a third formed a few months later in 2009 near Denver City, Texas. All three sinkholes were the result of solution mining operations for brine production from Upper Permian salt beds. The Eddy Co. sinkholes formed within the giant Empire oil and gas field, several kilometers from populated areas. In the aftermath of these events, another brine well operation was identified within the city limits of Carlsbad, New Mexico as having a similar geologic setting and pumping history. That well has been abandoned and geotechnical monitoring of the site has been continuous since 2008. Although there is no indication of imminent collapse, geophysical surveys have identified a substantial void in Permian salt beds beneath the brine well extending north and south beneath residential areas, a major highway intersection, a railroad, and an irrigation canal.
\end{abstract}

\section{Introduction}

Sinkholes and karst fissures formed in gypsum bedrock are common features of the lower Pecos region of west Texas and southeastern New Mexico. New sinkholes form almost annually, often associated with upward artesian flow of groundwater from karstic aquifers of regional extent that underlie evaporitic rocks at the surface (e.g., Martinez et al., 1998; Land, 2003a, 2006). A small but significant number of these sinkholes are of human origin, including the well-known Wink Sinks in Winkler Co., Texas (Figure 1). Wink Sink no. 1 formed in 1980 outside the small community of Wink, Texas, within the giant Hendrick oil field, destroying crude oil pipelines and oil field infrastructure. The sinkhole ultimately expanded to a diameter of $110 \mathrm{~m}$, with a total estimated volume of 159,000 cubic meters. Wink Sink no. 1 appears to have been largely inactive for the past 30 years, but in May, 2002 a new sinkhole formed less than $2 \mathrm{~km}$ south of Wink Sink no. 1. Wink Sink no. 2 is significantly larger than its predecessor, with a maximum width of $238 \mathrm{~m}$ and an estimated total volume of 1.3 million cubic meters. Both sinkholes are assumed to have formed by dissolution of salt beds in the Upper Permian Salado Formation (Figures 2 and 3), in association with improperly-cased abandoned oil and water supply wells (Johnson et al., 2003). Powers (2003) reports that a sinkhole that formed near Jal, New Mexico (Figure 1), was probably the result of Salado dissolution related to an improperly-cased water well. These three sinkholes all overlie the Middle Permian Capitan Reef aquifer. In the case of the Wink sinks, Johnson et al. (2003) observe that hydraulic head of water in the Capitan Reef is locally above the elevation of the Salado Formation. Undersaturated water rising along a borehole by artesian pressure may have contributed to subsurface dissolution and collapse of the Wink sinkholes.

Sinkholes in the greater Permian Basin region have also resulted from solution mining of Permian salt beds in the shallow subsurface. The Borger sinkholes, in Hutchinson Co., Texas, are associated with solution mining operations conducted to extract brine from the Upper Permian Flowerpot salt beds. Surface subsidence was first observed in 1964, and sonar surveys revealed a subsurface cavity that had migrated to within $137 \mathrm{~m}$ of the surface. Within the next 14 years two sinkholes $\sim 15 \mathrm{~m}$ deep and $50 \mathrm{~m}$ in diameter had formed above the cavern (Johnson et al., 2003). 


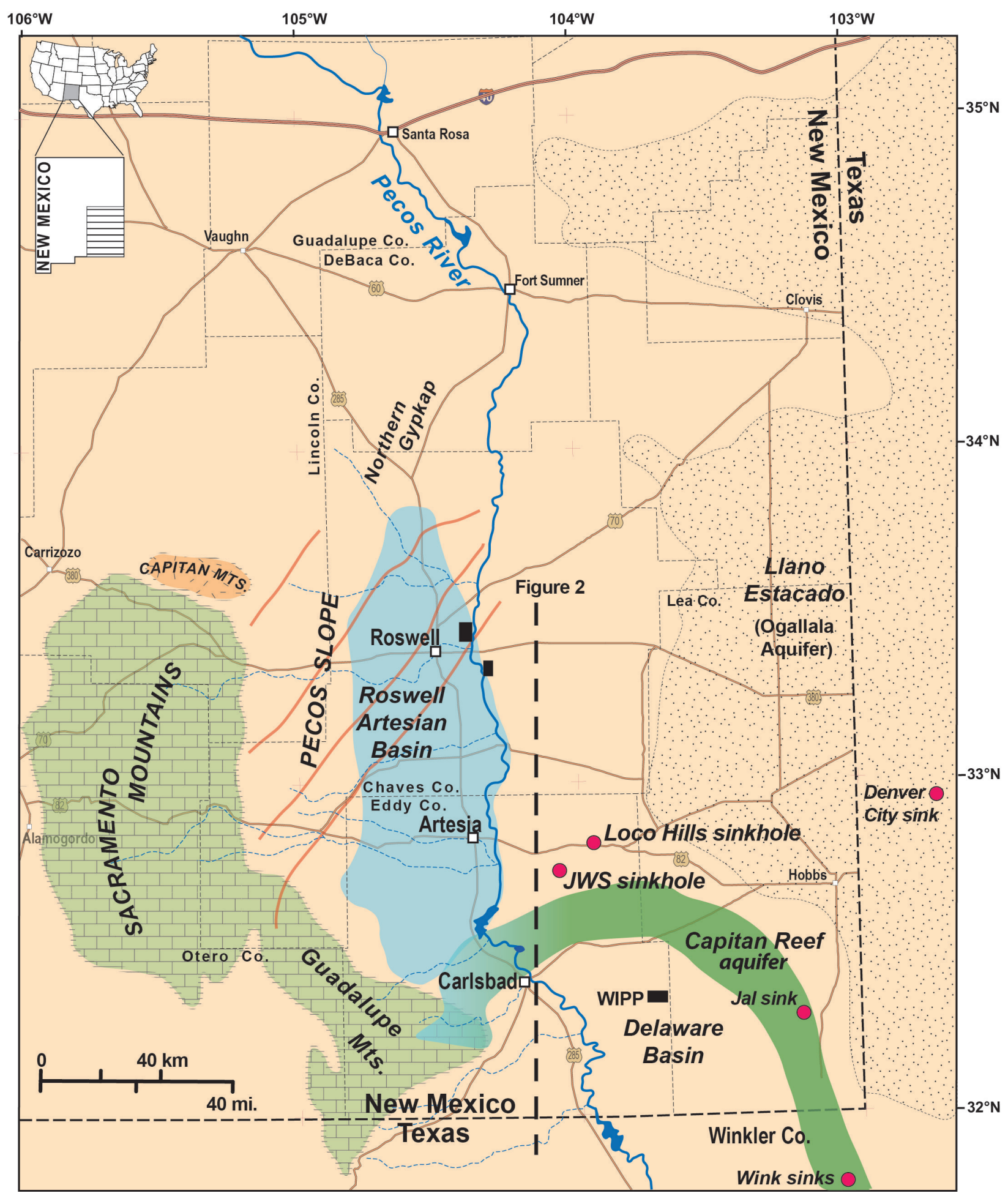

Figure 1. Regional map of the lower Pecos region of southeastern New Mexico and adjoining areas of west Texas, showing locations of sinkholes discussed in text, and their position with respect to the Capitan Reef. WIPP $=$ Waste Isolation Pilot Plant. 


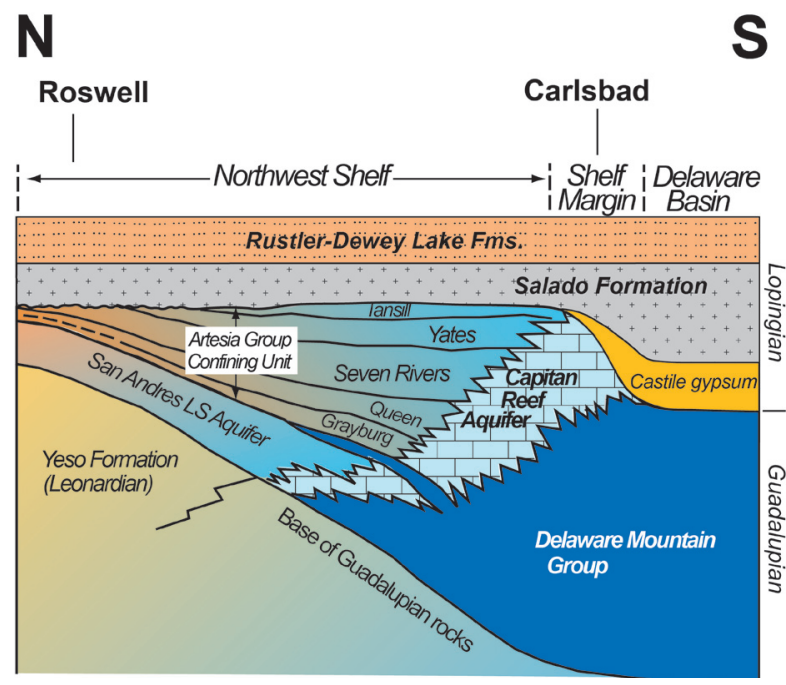

Figure 2. Diagramatic north-south stratigraphic section showing shelf-to-basin facies relationships in the Delaware Basin region. Line of section shown in Figure 1.

\section{Geologic setting}

The lower Pecos region includes the city of Carlsbad in Eddy Co., New Mexico (Figures 1 and 4). Evaporitic rocks, primarily gypsum, are widely distributed in the Carlsbad area both at the surface and in the subsurface (Bachman, 1984; Hill, 1996). Carlsbad is located on the Northwest Shelf of the Delaware Basin (Figures 1 and 2), a large hydrocarbon-producing sedimentary basin in west Texas and southeastern New Mexico (Land, 2003b). The uppermost part of the Delaware Basin section is comprised of $\sim 1700 \mathrm{~m}$ of redbeds and evaporites of Upper Permian (Lopingian) age (Lucas, 2006a; 2006b). This section includes the Salado Formation (Figures 2 and 3), which in the subsurface of the Delaware Basin consists of $\sim 710 \mathrm{~m}$ of bedded halite and argillaceous halite, with lesser amounts of anhydrite and polyhalite. Rare amounts of potassium salts (sylvite and langbeinite) occur in the the McNutt Potash Zone near the center of the formation (Cheeseman, 1978). Clastic material makes up less than $4 \%$ of the Salado (Kelley, 1971). Potash ore is mined from the McNutt Potash Zone in underground mines a few kilometers east of Carlsbad. The formation is also the host rock for the Waste Isolation Pilot Plant (WIPP), a repository for transuranic radioactive waste in eastern Eddy County (Figures 1 and 3).

The Salado Formation thins to the north and west by erosion, halite dissolution, and onlap onto the Northwest Shelf of the basin. Because of the soluble nature of Salado rocks, the unit is very poorly exposed in an "outcrop belt" $\sim 5 \mathrm{~km}$ east of the Pecos River valley (Figure 5). In that area the Salado is represented by 10 to $30 \mathrm{~m}$ of insoluble residue consisting of reddish-brown siltstone, occasional gypsum, and greenish and reddish clay in chaotic outcrops. In most areas the Salado outcrop is covered by a few meters to tens of meters of pediment gravels and windblown sand (Kelley, 1971; McCraw and Land, 2008).

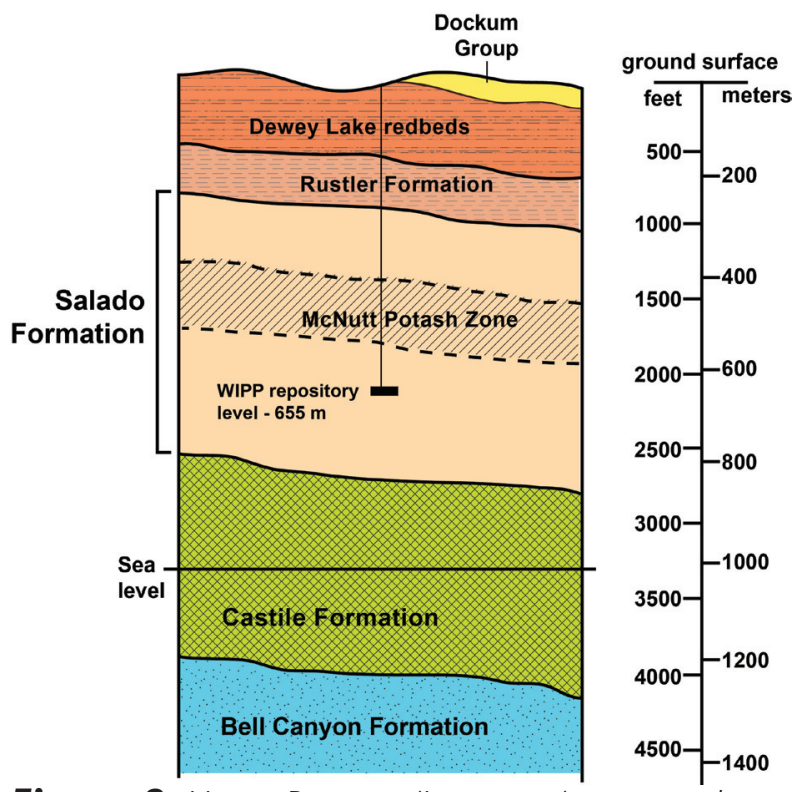

Figure 3. Upper Permian (Lopingian) stratigraphy in the northern Delaware Basin in the vicinity of the WIPP Site, southeastern New Mexico.

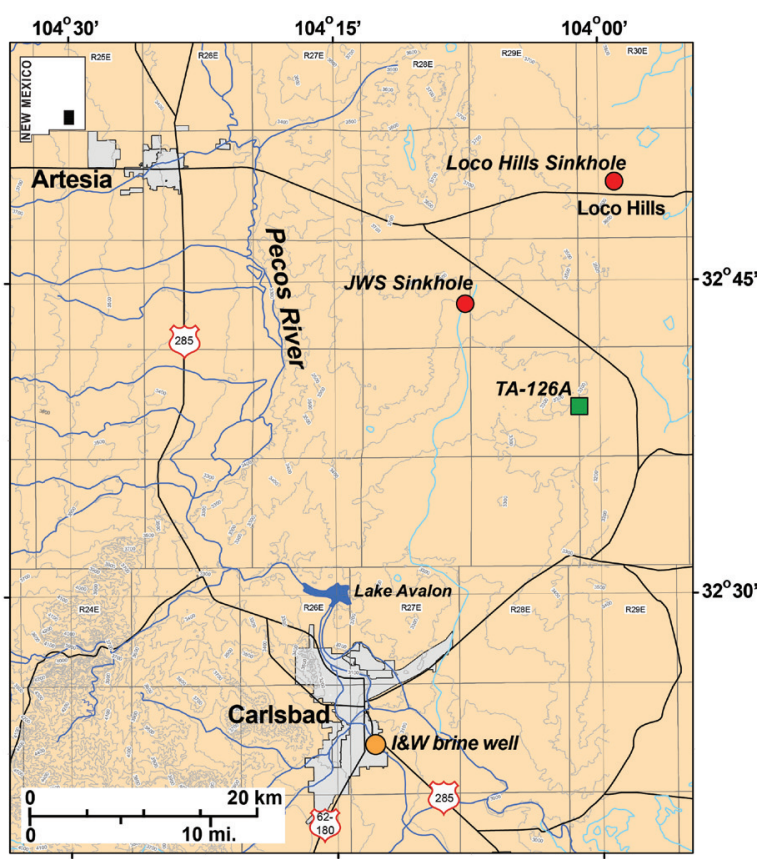

Figure 4. Map of study area in Eddy Co., New Mexico, showing locations of the Eddy County sinkholes. Southernmost filled circle shows the location of an abandoned brine well within city limits of Carlsbad. 


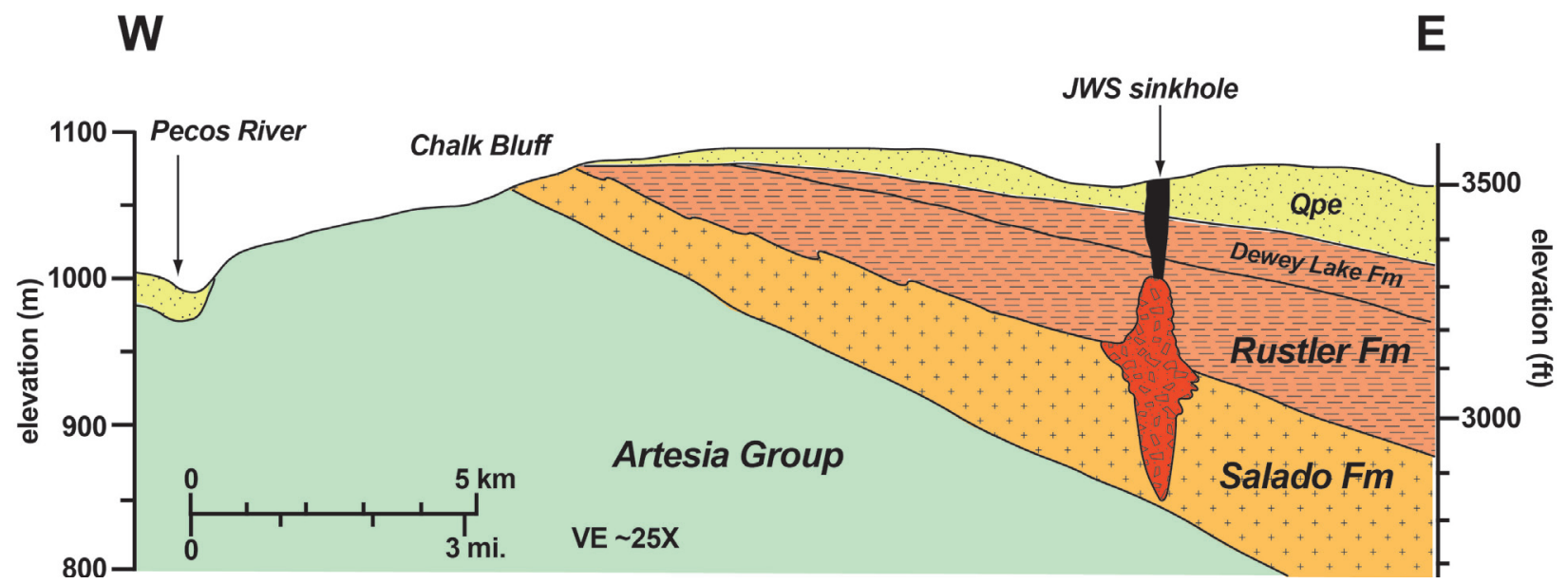

Figure 5. West-east cross-section showing stratigraphic section penetrated by JWS sinkhole. Qpe = Quaternary pediment gravels and windblown sand.

\section{Eddy Co. and Denver City sinkholes}

Around 8:15 on the morning of July 16th, 2008, a driver for a local water service company was inspecting a brine well located on state trust land $\sim 35 \mathrm{~km}$ northeast of Carlsbad. While on location the driver noticed a rumbling noise and quickly vacated the site. Minutes later, a large sinkhole abruptly formed, engulfing the brine well and associated structures (Figure 6). The well operator had been solution mining the Salado Formation by injecting fresh water and circulating it through the $86 \mathrm{~m}$ thick section of halite until the water reached saturation. The resulting brine was then sold as oil field drilling fluid. The brine well was being operated under permit from the New Mexico Oil Conservation Division (NMOCD).

This sinkhole, referred to as the JWS sinkhole from the initials of the well operator, was originally several tens of meters in diameter and filled with water to a depth of $\sim 12 \mathrm{~m}$ below land surface. Large concentric fractures developed around the perimeter of the sink, threatening the integrity of County Road 217, $100 \mathrm{~m}$ to the south. By July 28, the walls of the sink had developed an angle of about $45^{\circ}$ to within $\sim 20 \mathrm{~m}$ below ground level, above which the sides of the sink were vertical, and the water originally present had subsided into the subsurface (Figure 7). There are no significant sources of groundwater at shallow depths in the immediate vicinity of the JWS sinkhole. Thus we assume the water was solution mining fluid that had been forced up the debris chimney in the initial stages of collapse, and was now stored in pore space in the resulting collapse breccia in the subsurface cavern. By this time the sinkhole had attained a diameter of $\sim 111 \mathrm{~m}$, based on air photo interpretation, with an estimated depth of 45 m (Land and Aster, 2009).

Less than four months after collapse of the JWS sink, another brine well collapse occurred in northern Eddy Co. near the small community of Loco Hills (Figures 1 and 4), forming a sinkhole of similar dimensions. The Loco Hills sinkhole, which has subsequently been filled, was also the result of a brine well operation in the Salado Formation on state trust land. The well had been shut in three months earlier after it failed a mechanical integrity test as part of a statewide review of brine wells conducted in the aftermath of the JWS collapse. Then in July, 2009 another sinkhole abruptly formed near Denver City, Texas, $\sim 115 \mathrm{~km}$ east of Loco Hills (Figure 1). The Denver City sinkhole was also the product of a solution mining operation.

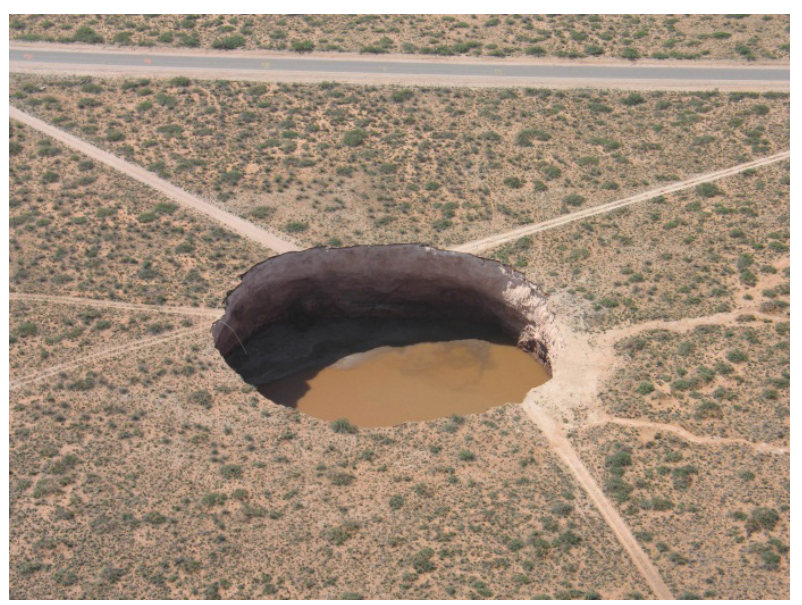

Figure 6. JWS sinkhole on 7/19/2008, three days after initial catastrophic collapse. Water in sink is $\sim 12$ $m$ below ground level. View to south, with County Road 217 in background. 


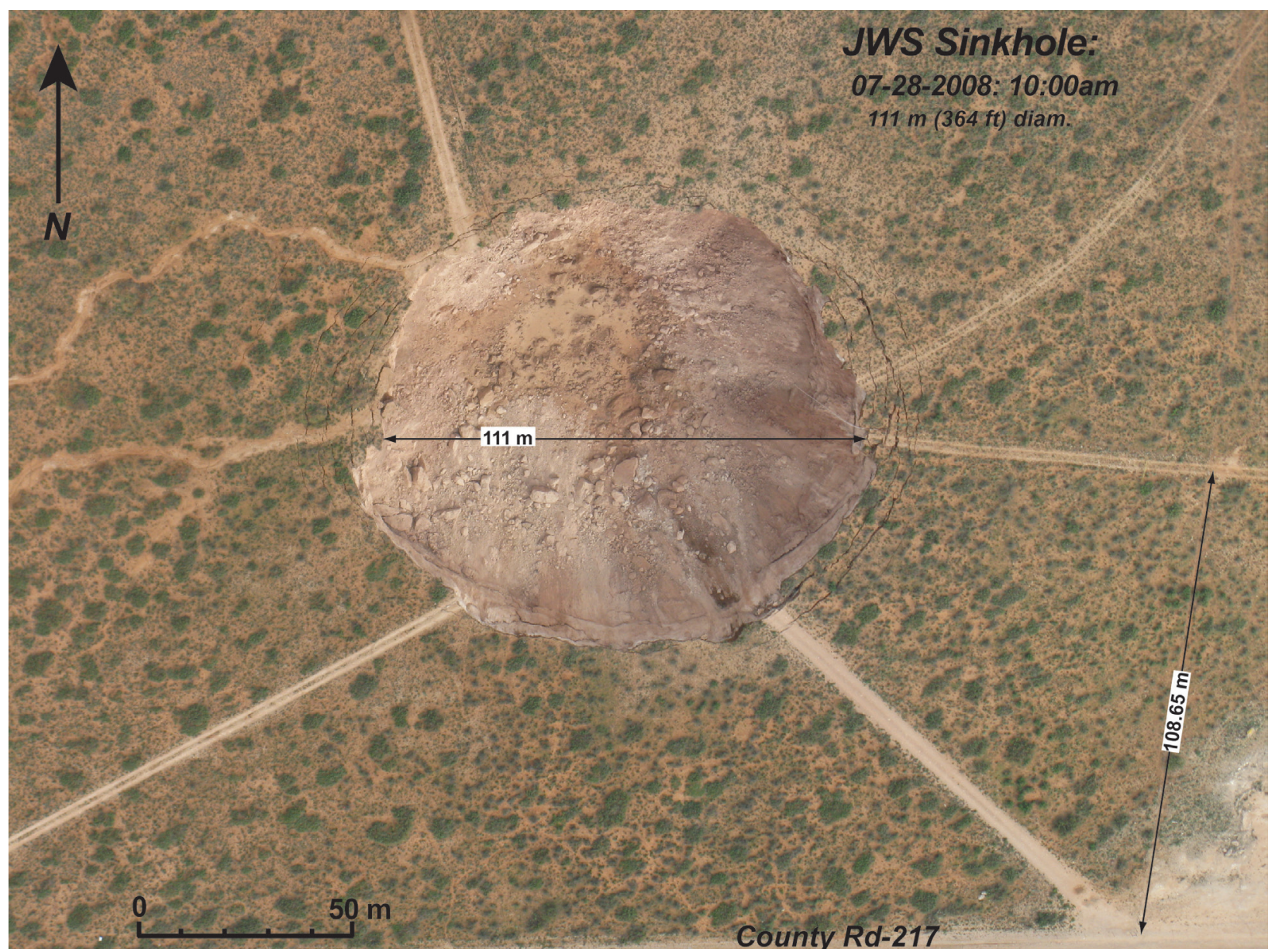

Figure 7. JWS sinkhole on $7 / 28 / 2008$, showing post-collapse draining and broadening. Note concentric fractures around margins of sink. Boulders in the sinkhole are approximately car-size.

\section{Seismic record}

On March 15, 2008, an EarthScope Transportable Array three-component broadband seismograph TA126 was installed $\sim 13 \mathrm{~km}$ southeast of the JWS sinkhole (Figure 4). This transportable seismograph is a component of the National Science Foundation's EarthScope USArray continental seismic investigation program. About 6 hours before surface disruption at the site of the brine well, TA126 began recording high frequency $(>5 \mathrm{~Hz})$ seismic signals, with vertical ground motion velocity amplitudes of $\sim 5$ microns/s (Figure 8 ).

These seismic events probably reflect subsurface spalling during upward stoping of the cavern roof, with seismic energy resulting from the fall of material into the solution cavity (Land and Aster, 2009).

\section{Solution mining}

During solution mining operations a subsurface cavern is excavated. Most cavern excavation occurs at the top of the void space, since the injected fresh water floats on top of the denser brine. A cushion of crude oil or diesel fuel is sometimes injected into the void to protect the cavern roof and ensure that cavern excavation occurs outward rather than upward. This procedure was not applied in the brine well operations that produced the JWS and Loco Hills sinkholes. To prevent surface subsidence and collapse, brine well operators in New Mexico are required to conduct annual pressure tests and downhole sonar surveys to assess the size and proportions of the cavern being excavated. However, borehole problems prevented the operator from conducting these surveys. Apparently, the mechanical strength of the mudstone and gypsum in the overlying Rustler and Dewey Lake Formations was insufficient to prevent upward stoping of the cavern roof, causing an unanticipated catastrophic surface collapse (Figure 9).

\section{I\&W brine well}

Formation of the Eddy Co. sinkholes in 2008 prompted NMOCD to review its regulations regarding brine well 


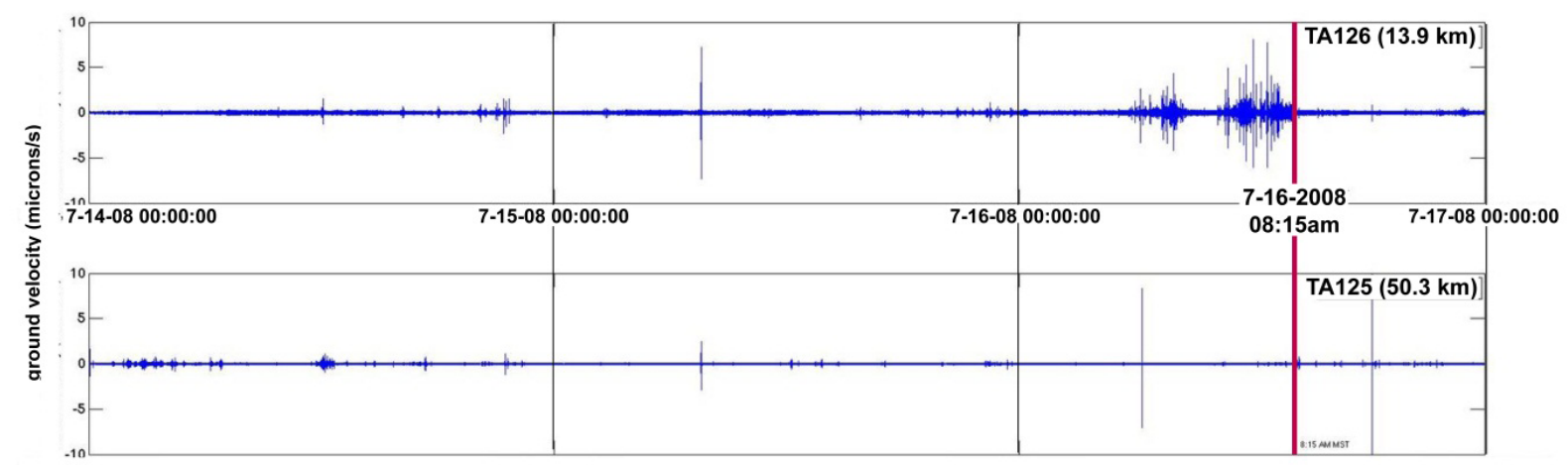

Figure 8. Transportable array seismograph TA126-A 3-day high-pass (filtered above $5 \mathrm{~Hz}$ ) record of vertical ground velocity (top), located $13.9 \mathrm{~km}$ southeast of the JWS sinkhole, showing more than 6 hours of apparent precursor ground motion associated with sinkhole formation. Estimated time of surface breaching (8:15am) indicated by vertical red line. Seismograph TA1 25 (lower plot), located $50.3 \mathrm{~km}$ from the site, showed no obvious candidate precursor signals.
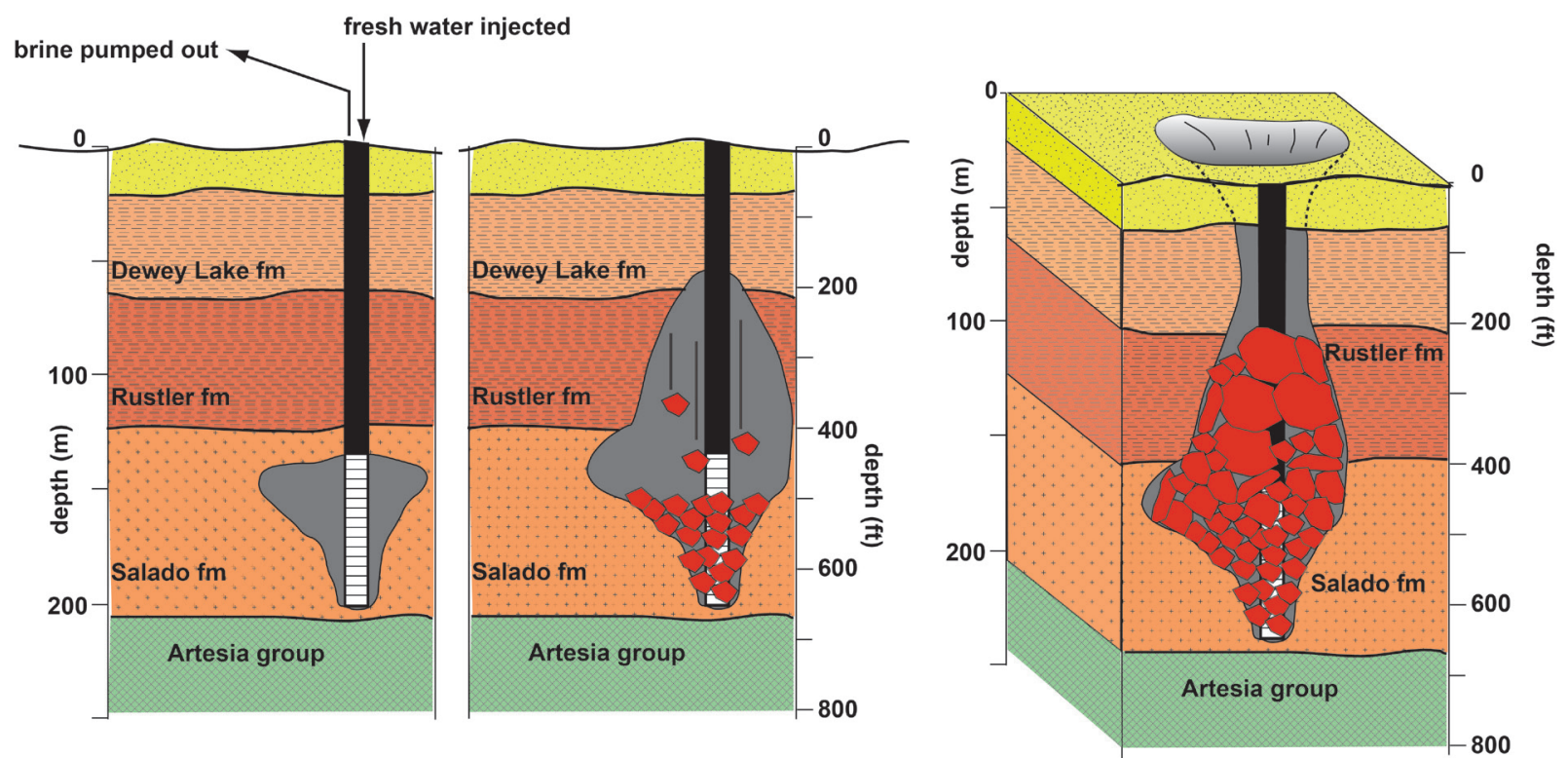

Figure 9. Sequence of events associated with solution mining that led to development of the JWS sinkhole. Unnamed uppermost section consists of $\sim 20 \mathrm{~m}$ of Quaternary sand, gravel, and calcrete.

operations in the southeastern New Mexico oil fields. During this review, the I\&W brine well was identified within the city limits of Carlsbad (Figure 4) as having a similar geologic setting and pumping history. However, unlike the JWS and Loco Hills sinkholes, which are located in relatively remote areas in northern Eddy County, the I\&W operation is sited in a more densely populated area within the city of Carlsbad near the BN\&SF rail line and the intersection of two major highways (Figure 4). The Carlsbad Irrigation District (CID) South Canal is about $50 \mathrm{~m}$ south of the wellhead, and the immediate area also includes a feed store, truck stop, mobile home park, and Jehovah's Witness church. A catastrophic collapse in this area would inflict extensive damage to individual property and civic infrastructure, and possibly cause fatalities.

Following the collapse of the JWS Sinkhole, NMOCD ordered closure of the I\&W brine well. The City of Carlsbad and Eddy County developed a monitoring, alarm, and emergency response system to prevent loss of life in the event that a catastrophic collapse should occur. Geotechnical monitoring of the site has been continuous since 2008, consisting of an array of tilt-meters and related devices that measure shifts, subsidence, and cracks in the immediate vicinity of the brine well. 


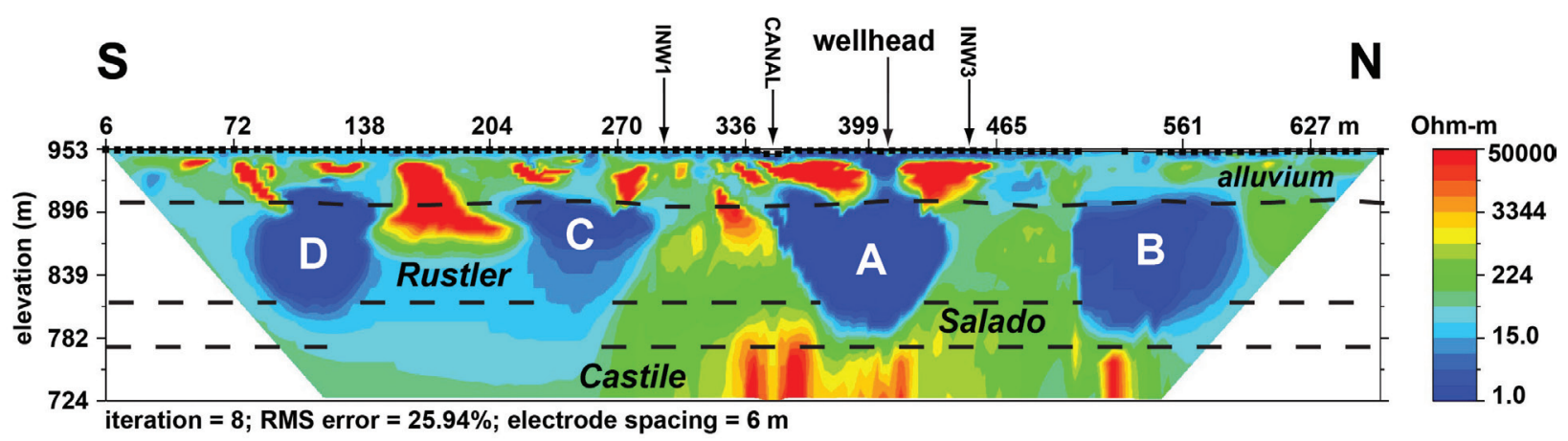

Figure 10. South-north electrical resistivity profile across I\&W brine well site. This line passes within 2 $m$ of the I\&W wellhead, thus crossing directly over the subsurface cavern excavated during solution mining operations. Low resistivity zones, shown in blue and purple, probably indicate brine-filled cavities or brine-saturated breccia zones. The low resistivity zones labelled A, B, C, and D correspond to potentially hazardous areas indicated in Figure 11.

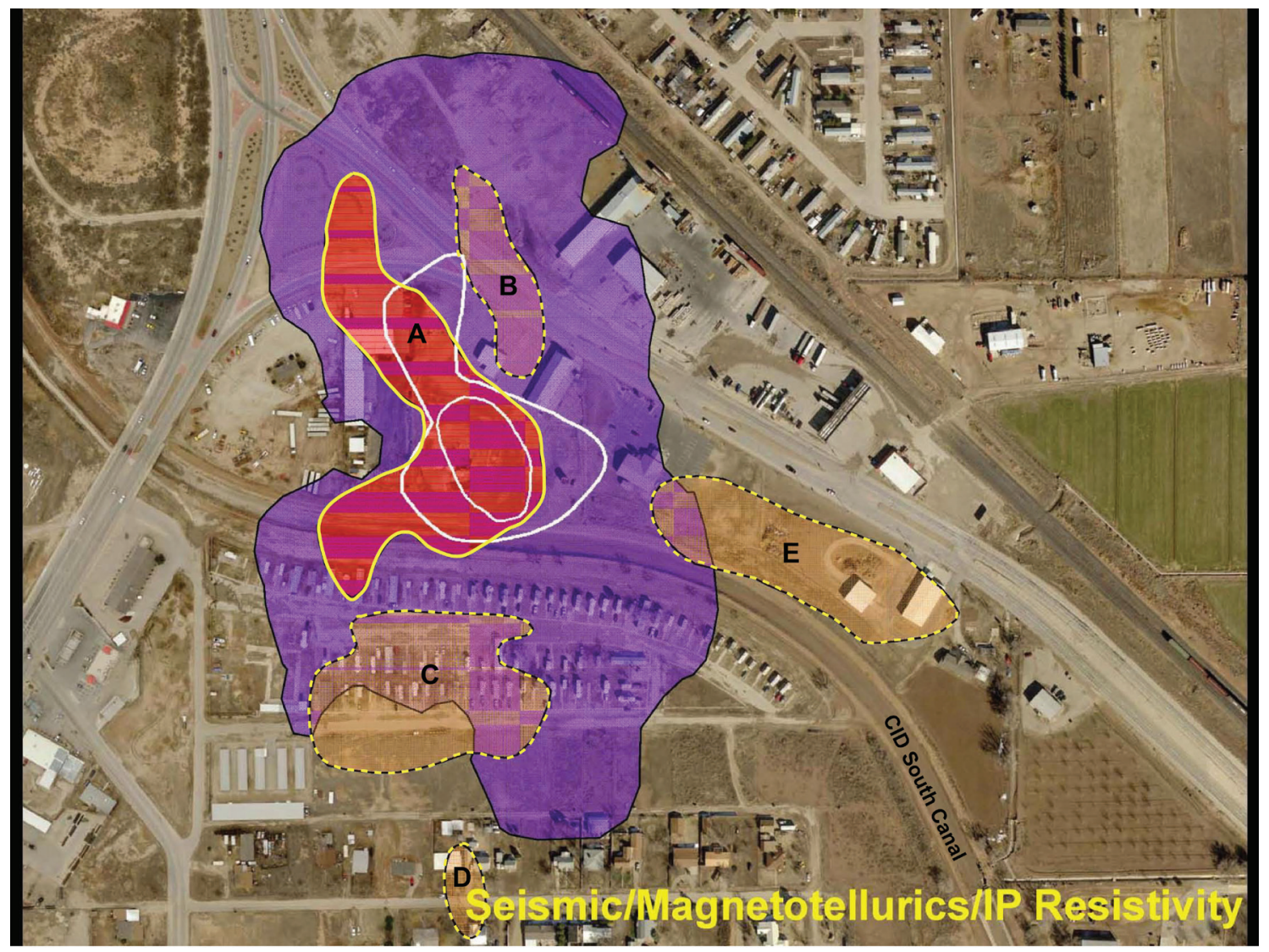

Figure 11. Geophysical surveys conducted at I\&W brine well facility from 2009 to 2011 . Low resistivity zones $A, B, C, D$, and $E$ defined by electrical resistivity survey are indicated by solid or dashed yellow lines; red filled area shows probable extent of the cavity excavated by the I\&W brine well, as defined by resistivity surveys. Purple shading shows area where magnetotelluric surveys identified subsurface void thickness greater than 3 meters. White outline indicates area where a cavern signature was identified on 2D seismic reflection surveys. Inner white oval shows the area of greatest seismic disruption. Note that none of the seismic lines extended south of the CID South Canal. 
NMOCD also initiated geophysical investigations, including electrical resistivity, magnetotelluric, and seismic reflection surveys, to determine the size, shape, and lateral extent of the cavity excavated by the I\&W solution mining operation. A Technical Advisory Subcommittee has discussed the possibility of filling the cavity, but only in general terms, since a reliable selection of the best methods and materials to prevent a collapse is not possible until site characterization is complete.

Electrical resistivity surveys of the I\&W brine well site, conducted by the National Cave and Karst Research Institute (NCKRI), indicate that the area is underlain by extensive low resistivity zones that represent either open cavities in the Rustler and Salado Formations caused by solution mining, and/or highly fractured and brine-saturated intervals within the Rustler Formation that may have been caused by sagging and collapse into underlying cavities (Land and Veni, 2011; 2012) . These low resistivity zones extend to the north beneath the intersection of highways 285 and 62-180, and south beneath residential areas south of the CID South Canal. The data suggest that solution mining of the Salado Formation has caused significant upward stoping into overlying Rustler strata (Figure 10). This interpretation is consistent with results from seismic reflection surveys (Goodman et al., 2009) and the magnetotelluric survey (Woods, 2011) of the I\&W site (Figure 11).

\section{Conclusions}

Sinkholes formed in evaporitic rocks are common features in the Permian Basin region of southeastern New Mexico and west Texas. A small but significant number of these features are of human origin, the product of improperly-cased water wells or abandoned oil wells, or solution mining of salt beds in the shallow subsurface.

Johnson (2002) observed that "most solution-mining collapses result from cavities formed 50-100 years ago, before modern-day engineering safeguards were developed. Proper, modern design has virtually eliminated this problem in new facilities." It would appear that developing engineering safeguards for solution mining is still an evolving science.

\section{References}

Bachman GO. 1984. Regional geology of Ochoan evaporites, northern part of Delaware Basin. New Mexico Bureau of Mines and Mineral Resources Circular 184.
Cheeseman RJ. 1978. Geology and oil/potash resources of Delaware Basin, Eddy and Lea Counties, New Mexico. In: Austin GS, editor. Geology and mineral deposits of Ochoan rocks in Delaware Basin and adjacent areas. New Mexico Bureau of Mines and Mineral Resources Circular 159: 7-14.

Goodman WM, Schneider JM, Gnage JD, Henard DA, Van Sambeek LL. 2009. Two-dimensional seismic evaluation of the I\&W brine cavern, Carlsbad, New Mexico. RESPEC Topical Report RSI-2083; [cited 2012 Nov 14]. Available from: http://www.emnrd.state.nm.us/OCD/documents/ RSI2083.pdf.

Hill CA. 1996. Geology of the Delaware Basin, Guadalupe, Apache, and Glass Mountains, New Mexico and west Texas. Permian Basin SectionSEPM Publication 96-39.

Johnson KS. 2002. Karst in evaporite rocks of the United States. Carbonates and Evaporites 17: 90-97.

Johnson KS, Collins EW, Seni SJ. 2003. Sinkholes and land subsidence owing to salt dissolution near Wink, Texas, and other sites in western Texas and New Mexico. In: Johnson KS, Neal JT, editors. Evaporite karst and engineering/environmental problems in the United States. Oklahoma Geological Survey Circular 109: 183-195.

Kelley VC. 1971. Geology of the Pecos country, southeastern New Mexico. New Mexico Bureau of Mines and Mineral Resources Memoir 24.

Land L. 2003a. Evaporite karst and regional ground water circulation in the lower Pecos Valley. In: Johnson KS. Neal JT, editors. Evaporite Karst and Engineering/Environmental Problems in the United States. Oklahoma Geological Survey Circular 109: 227-232.

Land L. 2003b. Regional geology of the Pecos Country. In: Johnson PS, Land L, Price LG, Titus F, editors. Water Resources of the Lower Pecos Region, New Mexico: Science, Policy, and a Look to the Future. New Mexico Bureau of Geology and Mineral Resources 2003 New Mexico Decision Makers Guidebook: 9-13.

Land L. 2006. Hydrogeology of Bottomless Lakes State Park. In: Land L, Lueth V, Raatz B, Boston P, Love D, editors. Caves and Karst of Southeastern New Mexico. New Mexico Geological Society Guidebook 57: 95-96.

Land L, Aster R. 2009. Seismic recordings of an anthropogenic sinkhole collapse. Proceedings of the Symposium on the Application of Geophysics to Engineering and Environmental Problems. Environmental and Engineering Geophysical Society 2009 Annual Meeting, Fort Worth, Texas: 511-519. 
Land L, Veni G. 2011. Electrical resistivity survey: I\&W brine well, Eddy Co., NM: Unpublished report submitted to New Mexico Oil Conservation Division, NM Dept. of Energy, Minerals and Natural Resources; [cited 2012 Nov 14]. Available from: http://www.emnrd.state.nm.us/OCD/documents/ NCKRIResistivityFinalReport.pdf

Land L, Veni G. 2012. Electrical resistivity surveys of anthropogenic karst phenomena, southeastern New Mexico. New Mexico Geology (in press).

Lucas SG. 2006a. Three Permian series. In: Land L, Lueth V, Raatz B, Boston P, Love D, editors. Caves and Karst of Southeastern New Mexico. New Mexico Geological Society Guidebook 57: 60-61.

Lucas SG. 2006b. Ochoa Group, not Series or Stage, upper Permian of west Texas and southeastern New Mexico. In: Land L, Lueth V, Raatz B, Boston P, Love D, editors. Caves and Karst of Southeastern New Mexico. New Mexico Geological Society Guidebook 57: 62-63.

Martinez JD, Johnson KS, Neal JT. 1998. Sinkholes in evaporite rocks. American Scientist 86: 38-51.

McCraw DJ, Land L. 2008. Preliminary Geologic Map of the Lake McMillan North 7.5-Minute Quadrangle Map, Eddy Co., New Mexico. New Mexico Bureau of Geology and Mineral Resources Open-File Geologic Map-167. 1:24,000.

Powers DW. 2003. Jal sinkhole in southeastern New Mexico: Evaporite dissolution, drill holes, and the potential for sinkhole development. In: Johnson KS. Neal JT, editors. Evaporite Karst and Engineering/ Environmental Problems in the United States. Oklahoma Geological Survey Circular 109: 219226.

Woods DA. 2011. Z-Scan review former I\&W facility, Carlsbad, New Mexico: DMT Technologies Final Report for EMNRD/Oil Conservation Division; [cited 2012 Nov 14]. Available from: http://www.emnrd.state.nm.us/OCD/documents/ IWMagnetotelluricReport.pdf. 
122 NCKRI SYMPOSIUM 2 I3TH SINKHOLE CONFERENCE 